\title{
Gaucher disease: expression and characterization of mild and severe acid $\beta$-glucosidase mutations in Portuguese type 1 patients
}

\author{
Olga Amaral ${ }^{1}$, Ana Marcão ${ }^{2}$, MC Sá Miranda ${ }^{1}$, Robert J Desnick ${ }^{3,4}$ and Marie E Grace ${ }^{3}$ \\ ${ }^{1}$ Instituto de Genética Médica Jacinto Magalhães, Unidade de Enzimologia; ${ }^{2}$ nstituto de Biologia Molecular e \\ Celular, Unidade de Neurobiologia Genética, Porto, Portugal; Departments of ${ }^{3}$ Human Genetics and ${ }^{4}$ Pediatrics, \\ Mount Sinai School of Medicine, New York, USA
}

Type 1 Gaucher disease (GD), the most prevalent lysosomal storage disease, results from the deficient activity of acid $\beta$-glucosidase. Molecular analysis of 12 unrelated Portuguese patients with type 1 GD identified three novel acid $\beta$-glucosidase mutations (F109V, W184R and R395P), as well as three previously reported, but uncharacterized, lesions (R359Q, G377S and N396T). The type 1 probands were either heteroallelic for the well-characterized common lesion, N370S, and the F109V, W184R, R359Q or N396T lesions or homoallelic for the G377S or N396T mutations. Expression of the W184R, R359Q, and R395P mutations revealed very low specific activities based on cross-reacting immunologic material (CRIM SAs of $0.0004,0.016$ and 0.045 , respectively), consistent with their being found only in type 1 patients who had a neuroprotective N370S allele. In contrast, the F109V, G377S and N396T alleles had significant acid $\beta$-glucosidase activity (CRIM specific activities of $0.15,0.17,0.14$, respectively), in agreement with their being mild type 1 alleles. Thus, these studies identified additional acid $\beta$-glucosidase mutations in the Portuguese population and demonstrated that the G377S and N396T mutations were neuroprotective, consistent with the mild clinical phenotypes of the type 1 patients who were homoallelic for the G377S and N396T lesions. European Journal of Human Genetics (2000) 8, 95-102.

Keywords: baculovirus; mutation analysis; Gaucher; neuroprotective allele; phenotype

\section{Introduction}

Gaucher disease (GD) is an inherited storage disorder resulting from the deficiency of acid $\beta$-glucosidase (E.C.3.2.1.45) and the lysosomal accumulation of its undegraded substrate, glucosylceramide, particularly in the cells of the reticuloendothelial system. ${ }^{1,2}$ The majority (about 95\%) of GD cases have non-neuronopathic or type 1 disease and present with systemic features including pancytopenia, hepatosplenomegaly and skeletal involvement. ${ }^{3}$ Patients with neurologic GD present with either an acute (type2) or subacute (type3) course.

\footnotetext{
Correspondence: Marie E Grace, PhD, Department of Human Genetics, Box 1498, Mount Sinai School of Medicine, Fifth Avenue and 100th Street, New York, NY 10029. Tel: +1 212659 6778; Fax: +1212 849 2508; E-mail: grace@msvax.mssm.edu

Received 16 April 1999; revised 17 September 1999; accepted 11

November 1999
}

The isolation and sequencing of the full-length cDNA and the entire genomic sequence, ${ }^{4-6}$ provided the opportunity to identify common disease-causing mutations, determine their frequencies, and identify genotype/phenotype correlations. To date, over 120 mutations have been identified in the acid $\beta$-glucosidase gene; ${ }^{7,8}$ (online compilation [http://www.uwcm.ac.uk/uwcm/mg/hgmd0.html ${ }^{9}$ ), including base substitutions causing missense, nonsense and splicing mutations, small and large insertions and deletions, and complex rearrangements with the pseudogene located $16 \mathrm{~kb}$ downstream. ${ }^{6}$ Of these mutations, only a few have been proven to be common: the N370S lesion in the Ashkenazi Jewish and the Portuguese populations and the panethnic L444P mutation. ${ }^{10-13}$

Prediction of disease type and severity by characterizing a patient's genotype has been difficult since most of the mutations identified are rare or private. In fact, most nonconsanguineous GD patients, with the notable exception of 
Ashkenazi, Norbottnian, and Portuguese patients, are heteroallelic for a rare or private allele. However, genotype/ phenotype correlations have been possible for the most frequently identified mutations, N370S and L444P. ${ }^{7,14-18}$ The presence of at least one N370S allele precludes development of neurological manifestations, even if the heteroallele is completely inactive; ${ }^{19,20}$ and homoallelism for the L444P mutation is generally predictive of neurological disease. ${ }^{21-24}$ Nonetheless, significant phenotypic variability occurs within the subtypes, ${ }^{25,26}$ and in particular within typel GD, as illustrated by patients homoallelic for the N370S allele, whose condition, although primarily mild, can range from clinically asymptomatic to severely involved with massive hepatosplenomegaly and debilitating bone disease. Of note, type 1 GD patients homoallelic or heteroallelic for the N370S allele are unusually prevalent among Ashkenazi Jewish and non-Jewish Portuguese patients, the carrier frequencies being about 1 in 17.5 and 1 in 118 in these populations, respectively. ${ }^{10,13}$

The identification and expression of acid $\beta$-glucosidase mutations is useful for understanding the normal function of this lysosomal hydrolase and for further delineation of genotype/phenotype correlations in GD, especially in nonJewish populations. ${ }^{12,15}$ Screening for four mutations (N370S, L444P, G377S and N396T) in the Portuguese population, where type $1 \mathrm{GD}$ is the most prevalent lysosomal storage disease (being some 25 times more frequent than the neu- ronopathic forms), detected $85 \%$ of mutant or about $15 \%$ unknown alleles. ${ }^{27}$ In this communication, three new mutations (F109V, W184R, R395P) and three previously reported

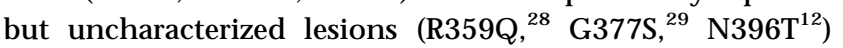
were detected in 12 Portuguese patients with type 1 GD. Heterologous expression and characterization studies confirmed causality of the mutations for GD, identified three mild alleles (F109V, G377S and N396T) and led to greater insight into the roles of individual residues in maintaining acid $\beta$-glucosidase function.

\section{Materials and methods Patient descriptions}

The clinical and laboratory features of the 12 Portuguese type 1 patients studied are summarized in Table 1 . The use of human materials was approved by the Institute of Medical Genetics Jacinto de Magal hães.

\section{Reagents}

Triton X-100 and NBD-glucocerebroside (NBD-GIC) were obtained from Sigma Chemical Co. (St Louis, MO, USA). 4-methylumbellifery 1- $\beta$-D-glucopyranoside (4MU- $\beta$-GIC) was from Genzyme Corp. (Cambridge, MA, USA) and SigmaAldrich Quimica (Madrid, Spain). Sodium taurocholate and

Table 1 Clinical and laboratory features of the Portuguese type 1 Gaucher disease patients

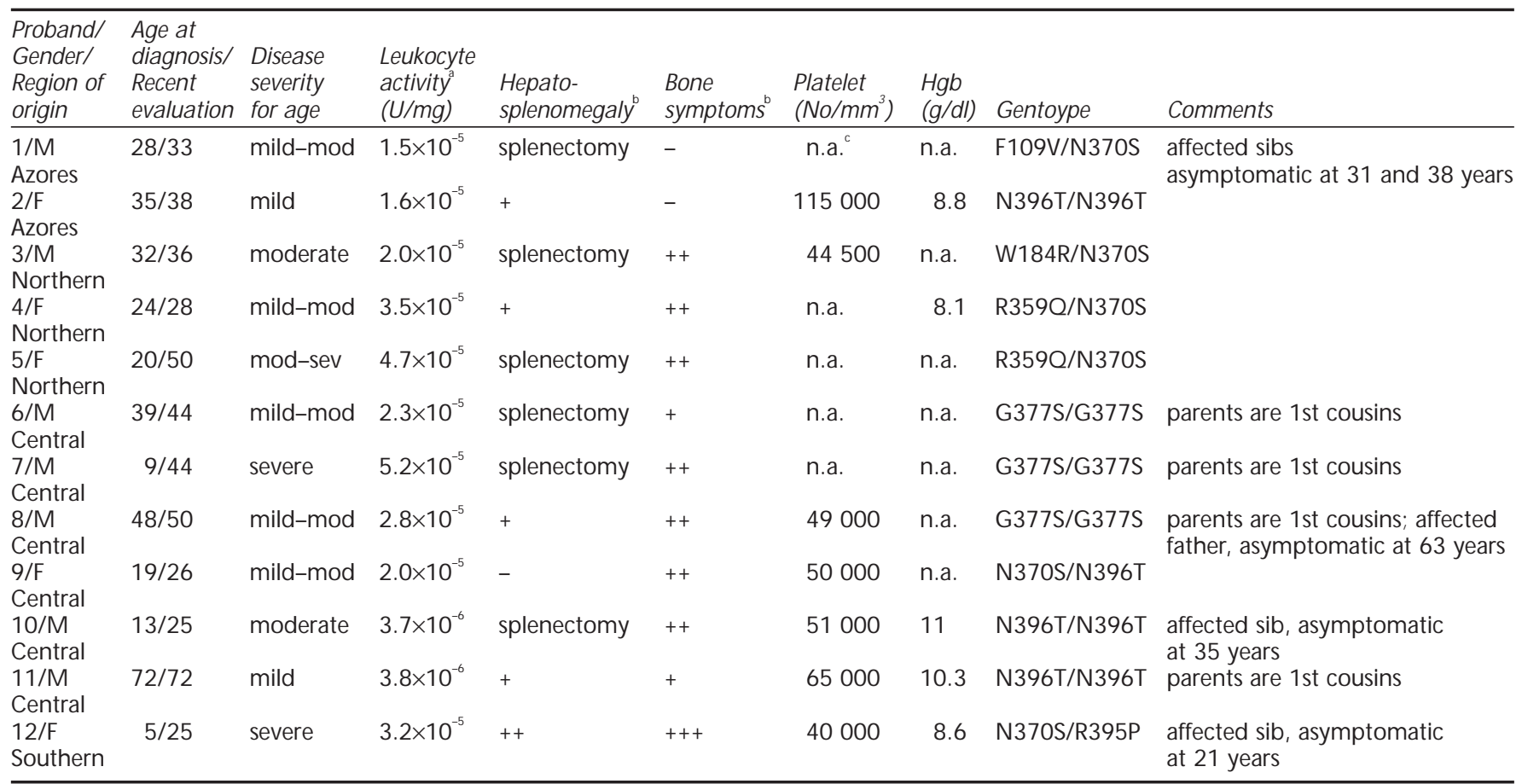

anormal range of enzymatic activity, $1.1-2.8 \times 10^{4} \mathrm{U} / \mathrm{mg}$ towards $4 \mathrm{mmU}$ glucopyranoside. $\quad{ }^{\mathrm{b}}+\mathrm{t}$ mild; + : moderate; +1 : severe; $-:$ minimal to none. 'n.a.: not available. 
deoxynojirimycin were purchased from CalBiochem-Novabiochem (La Jolla, CA, USA). The Sculptor ${ }^{\mathrm{TM}}$ In Vitro M utagenesis System kit was from Amersham (Arlington, IL, USA, and Amersham, England). Spodoptera frugiperda cells, Baculogold ${ }^{\circledR}$ linearized DNA, and the baculovirus transfer vector, pVL1392, were purchased from PharMingen (San Diego, CA, USA). Restriction enzymes and Taq DNA polymerase were from Boehringer Mannheim (Mannheim GMBH, Germany).

\section{DNA isolation, PCR amplification and mutation detection}

Genomic DNA was isolated from skin fibroblasts or peripheral blood using standard techniques. ${ }^{30}$ Initial screening for two common (N370S, L444P) and several rare but nonfamily-specific (84GG, IVS2 ${ }^{+1}, \mathrm{R} 463 \mathrm{C}, \mathrm{R} 496 \mathrm{H}, \mathrm{D} 409 \mathrm{H}$, R120Q, P122S, K157Q, Y212H, F216Y, W312C, G325R, C342G, D409V, P415R, RecTL, and RecNci) mutations s $^{21,31-44}$ as well as two mutations found in the Portuguese population, $\mathrm{G} 377 \mathrm{~S}^{29}$ and N396T, ${ }^{12}$ was performed by polymerase chain reaction (PCR) amplification and restriction digestion or allele specific oligonucleotide hybridization. ${ }^{31,45,46}$

To detect the unknown acid $\beta$-glucosidase mutations, the complete coding region and adjacent intron/exon boundaries were amplified directly from genomic DNA (or through nested PCR) and subjected to non-radioactive SSCP analysis. $^{12}$ The primers used for the exons in which the novel mutations were found follow: Exon 4, 5'-gggtactgatacccttatt$3^{\prime}$ and 5'-gggcagagtgagattctgcc-3'; Exon 6 and 8 (nested PCR), 1st PCR: 5'-ctcggactaccatatcttgatca-3' and 5'-gatgggactgtcgacaaagt-3', 2nd PCR (Exon 6) 5'-gtgttccaactctgggtgct-3' and 5'-taaatgggaggccagtcct-3', 2nd PCR (Exon 8) 5'-gatcagttgctcttcctttg-3' and 5'-tttgcaggaagggagactg-3'; Exon 9 (nested PCR), 1st PCR: 5'-aaccatgattccctatcttc-3' and 5'-acgtactctcatctttttgg-3', 2nd PCR: 5'-ccagtgttgagcctttgtct-3' and 5'-gtatggtccggatagtagag-3'.

The relevant PCR products with abnormal electrophoretic mobility were further examined by direct sequencing (Sequenase Version 2.0, USB, Cleveland, Ohio, USA) of the asymmetric PCR generated products. Each mutation identified was confirmed by direct sequencing or restriction analysis of genomic DNA from the proband and affected family members. Genomic DNAs from 50 randomly selected un related normal individuals were screened for the F109V, W184R, and R359P mutations by restriction digestion or SSCP analysis, as described above. The designations for the mutations refer to the position of the amino acid substitution, where amino acid one is the $\mathrm{N}$-terminus of the mature protein. The cDNA base numbers refer to the position of the nucleotide in the CDNA, ${ }^{4,47}$ where nucleotide one is the $A$ in the first ATG. The genomic designations are based on the updated acid $\beta$-glucosidase sequence ${ }^{6,48}$ available from GenBank [http:/ /www.ncbi.mlm.nih.gov/Entrez/nucleotide.html], accession number J03059 (8/95). The first nucleotide of exon 1 is at genomic position 1230 .

\section{Construction of expression plasmids}

Point mutations for F109V, W184R, R359Q, G377S, R395P, and N396T were introduced into the acid $\beta$-glucosidase cDNA by an M13mp19-based oligonucleotide-directed site-specific mutagenesis procedure (Sculptor $^{\mathrm{TM}}$ In Vitro Mutagenesis System) employing the phosphorothioate selection method $^{49,50}$ as previously described. ${ }^{51,52}$ The complete sequence of each mutagenized cDNA was determined to confirm that no spurious mutations were incorporated during the mutagenesis procedure. The mutant cDNAs were then cloned into the EcoRI site of the baculovirus expression vector, pVL1392. The final acid $\beta$-glucosidase cDNA inserts in the expression plasmid were $1562 \mathrm{bp}$ fragments beginning 12 bp upstream of the second ATG, ending at the stop codon, and containing the correct amino acid (arginine) at position 495.

\section{Construction and purification of recombinant baculovirus}

Recombinant baculovirus containing each of the different acid $\beta$-glucosidase cDNAs (normal in the sense [NI] and antisense [Rev] directions, F109V, W184R, R359Q, G377S, R395P, and N396T) were produced in cloned Spodoptera frugiperda (Sf9) cells by cal cium phosphate-mediated tran sfection and homologous recombination between the expression plasmid and baculovirus genomic DNA (Baculogold $\AA$ ) as described. ${ }^{53}$ Pure recombinant baculovirus clones containing the normal or mutant cDNA for acid $\beta$-glucosidase were isolated by plaque hybridization, amplified, titered, and used at a multiplicity of infection greater than 10 to infect Sf9 cells. ${ }^{53}$ The previously characterized common mutations, N370S and L444P, ${ }^{51,52,54,55}$ were re-expressed for comparative purposes.

\section{Immunoblotting}

Immunoelectroblotting using a polyclonal anti-human acid $\beta$-glucosidase antibody was conducted as described. ${ }^{56}$ In brief, Sf9 cells infected with pure recombinant virus were harvested 3 days post-infection. The pellets were sonicated in $0.04 \mathrm{M}$ citrate/phosphate buffer, $\mathrm{pH} 5.5$, containing $1 \mathrm{~mm}$ EDTA, $4 \mathrm{~mm} \beta$-mercaptoethanol, $0.1 \%$ Triton $\mathrm{X}-100$, and $0.1 \%$ sodium taurocholate, using a probe sonicator (Heat Systems-UItrasonics, Inc, Framingdale, NY, USA). Aliquots of the clarified $(875 \mathrm{Xg} ; 20 \mathrm{~min})$ crude sonicates containing determined amounts of protein and enzymatic activity were run on tricine-SDS-polyacrylamide gels ${ }^{57}$ and immunoblotted. Specific activities based on the amount of cross-reacting immunological material, CRIM specific activity (CRIM SA), were determined as described. ${ }^{51,52,54}$ The relative amounts of CRIM per unit of glucosylceramide-cleaving activity for each mutant allele was determined by computer analysis of the immunoblotting membrane using the $\mathrm{NIH} \mathrm{Image}{ }^{\mathrm{TM}}$ program, version 1.60, and referenced to that of the normal enzyme. To illustrate: computer assisted comparison of the mature about $63 \mathrm{kDa}$ band of the normal and F109V enzyme proteins 


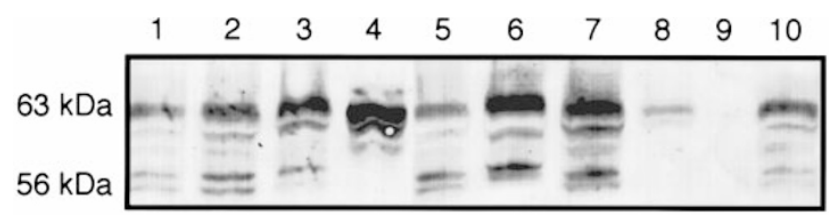

Figure 1 Immunoblot of the normal and mutant acid $\beta$-glucosidases expressed in Sf9 cells. Lane 1, F109V $\left(1.0 \times 10^{-4} \mathrm{U}, 15 \mu \mathrm{g}\right)$; lane2, W184R $\left(1.0 \times 10^{-6} \mathrm{U}, 15 \mu \mathrm{g}\right)$; lane3, R359Q $\left(1.9 \times 10^{-5} \mathrm{U}, 15 \mu \mathrm{g}\right)$; lane 4, N370S $\left(3.5 \times 10^{-4} \mathrm{U}, 15 \mu \mathrm{g}\right)$; lane5, G377S $\left(1.1 \times 10^{-4} \mathrm{U}, 15 \mu \mathrm{g}\right)$; lane6, R395P $\left(7.5 \times 10^{-5} \mathrm{U}, 15 \mu \mathrm{g}\right)$; lane7, N396T $\left(1.9 \times 10^{-4} \mathrm{U}, 15 \mu \mathrm{g}\right)$; lane8, L444P $\left(2.0 \times 10^{-5} \mathrm{U}, 15 \mu \mathrm{g}\right)$; lane 9 , the antisense construct $(10 \mu \mathrm{g})$; and lane 10 , Normal $\left(9.6 \times 10^{-4} \mathrm{U}, 10 \mu \mathrm{g}\right)$. See text for details.

(Figure1, lanes 10, and 1, respectively) demonstrated the immunoblot signal for the F109V mutant $\left(1.0 \times 10^{-4} \mathrm{U}\right)$ was about 0.7 times that for the expressed normal enzyme $\left(9.6 \times 10^{-4} \mathrm{U}\right)$. The CRIM SA for the F109V mutant enzyme is calculated as the relative units of enzymatic activity divided by the relative CRIM (ie $0.1 / 0.7=0.15$ ). F109V had a CRIM SA that was $15 \%$ of that for normal acid $\beta$-glucosidase, representing a 6.7 -fold reduction in catalytic efficiency or turnover rate.

\section{Enzyme assays}

Aliquots of the crude sonicates, prepared as described above, were assayed for acid $\beta$-glucosidase activity using the fluorescently-labeled natural substrate NBD-GC (12-[N-methyl$\mathrm{N}$-(7-nitrobenz-2-oxa-1,3-diazol-4-yl)]dodecanoyl-sphingosyl-1-O- $\beta$-D-glucopyranoside or NBD-glucosylceramide), or the synthetic substrate, 4-methylumbelliferyl$\beta$-D-glucopyranoside (4MU-GIc). The final reaction mixtures for the natural substrate contained $0.3 \mathrm{~mm} N B D-G C$ (reaction volume of 100 or $200 \mu \mathrm{L}$ ) in $0.04 \mathrm{M}$ citrate/phosphate buffer, $\mathrm{pH} 5.5,1 \mathrm{~mm}$ EDTA, $4 \mathrm{~mm} \beta$-mercaptoethanol, 0.25\% Triton $X-100$, and $0.25 \%$ sodium taurocholate. The W184R mutant also was assayed in the presence of $2.5 \mathrm{~mm}$ conduritol $B$ epoxide (CBE). The NBD-GC assays were terminated and processed as described. ${ }^{58}$ The fluorescence of the extracted reaction products were read using a Farrand Optical System 3 spectrofluorometer (Optical Technology Devices, Elmsford, NY, USA). Background levels were determined by comparison with results obtained from Sf9 cells infected with recombinant baculovirus containing the cDNA for acid $\beta$-glucosi dase in the antisense direction (Rev). The contribution to turnover of the synthetic $4 \mathrm{MU}-\mathrm{Glc}$ substrate in the crude lysates due to the expressed human acid $\beta$-glucosidase enzymes was calculated by determining the CBE inhibitable activity. ${ }^{59}$ Aliquots of the crude sonicates assayed were first incubated at pH 5.2 for $0.5 \mathrm{~h}$ at room temperature in the presence and absence of $1 \mathrm{~mm}$ CBE before being assayed for $2 \mathrm{~h}$ at $37^{\circ} \mathrm{C}$. The final assay mixtures (reaction volume of $60 \mu \mathrm{L}$ ) contained $0.1 / 0.2 \mathrm{M}$ citrate/phosphate buffer, pH 5.2, 1 mм EDTA, 4 mм $\beta$-mercaptoethanol, $0.25 \%$ Triton $\mathrm{X}-100$, and $0.25 \%$ sodium taur- ocholate. The $4 \mathrm{MU}-\mathrm{Glc}$ reaction was terminated by raising the $\mathrm{pH}$ with the addition of $1 \mathrm{~m}$ glycine. The difference between the activity with and without CBE was determined for each expressed allele. One unit $(U)$ of acid $\beta$-glucosidase activity was that amount of enzyme that hydrolyzed one micromole of susbtrate per $\min$ at $37^{\circ} \mathrm{C}$.

\section{Inhibition of expressed normal and mutant acid $\beta$-glucosidases by active site directed inhibitors}

Aliquots of crude lysates were assayed in the absence or presence of CBE and deoxynojirimycin (DNM). Concentrated aqueous stock solutions of CBE and DNM were made such that aliquots of $0-50 \mu \mathrm{L}$ gave the desired final concentrations in the $200 \mu \mathrm{L}$ reaction mixture. The assay conditions employing the synthetic $4 \mathrm{MU}-$ Glc substrate were as described above. The $\mathrm{IC}_{50}$ (the concentration of inhibitor resulting in $50 \%$ reduction in activity) values for $\mathrm{CBE}$ for the normal and mutant acid $\beta$-glucosidases were determined from a plot of activity remaining versus inhibitor concentration (0-600 $\mu \mathrm{M})$ after subtracting the $4 \mathrm{MU}$-GIc activity remaining at $3 \mathrm{~mm} C B E$ (which represents the non-CBE inhibitable endogenous Sf9-derived activity). Inhibition by DNM was assessed by determining the percentage of inhibition resulting from a single high concentration of DNM $(600 \mu \mathrm{M})$.

\section{Results \\ Identification of acid $\beta$-glucosidase mutations}

Complete SSCP analysis of the acid $\beta$-glucosidase coding region and intron/exon boundaries from non-Jewish Portuguese patients with type 1 GD (Table1) resulted in the identification of three new (F109V, W184R and R395P) and three rare, but uncharacterized, missense mutations (R359Q, ${ }^{28} \mathrm{G}^{2} 77 \mathrm{~S},{ }^{29}$ and $\mathrm{N}^{296 \mathrm{~T}^{12}}$ ). Table2 summarizes the nucleotide substitutions and the corresponding changes at the protein level for each mutation. The only other allele identified in these patients was the common N370S mutation. None of these mutations were derived from the tightly linked pseudogene. ${ }^{6}$ The W184R mutation was previously reported only as part of a complex allele ${ }^{36}$ found in an Ashkenazi/Sephardic Jewish type1 GD patient containing seven missense mutations (Complex C: R120W + W184R + $\mathrm{N} 188 \mathrm{~K}+\mathrm{V} 191 \mathrm{G}+\mathrm{S} 196 \mathrm{P}+\mathrm{G} 202 \mathrm{R}+\mathrm{F} 213 \mathrm{I})$, of which all but the W184R mutation occurred in the pseudogene sequence.

As indicated in Table2, five of the six mutations altered a restriction site, facilitating the screening of family members to confirm the lesions. Additionally, to rule out any of the three newly identified mutations being benign polymorphisms, genomic DNA from 50 randomly selected normal Portuguese individuals was screened for the F109V, W184R and R395P mutations by restriction digestion and/or SSCP analysis. None of the 100 alleles screened had any of these new base substitutions. 
Table 2 Mutations identified in Portuguese patients with type 1 Gaucher disease

\begin{tabular}{|c|c|c|c|c|c|c|}
\hline Designation & Exon & $\begin{array}{l}\text { CDNA } \\
\text { position }^{a}\end{array}$ & $\begin{array}{l}\text { Genomic } \\
\text { position }^{a}\end{array}$ & Codon change & $\begin{array}{l}\text { Amino acid } \\
\text { change }\end{array}$ & $\begin{array}{l}\text { Restriction site } \\
\text { change }\end{array}$ \\
\hline F109V & 4 & 442 & 2943 & ITC $\rightarrow$ GTC & Phe $^{109} \rightarrow$ Val & + Mae II \\
\hline W184R & 6 & 667 & 4343 & $\underline{\overline{\mathrm{T}} G G} \rightarrow \underline{\mathrm{C} G G}$ & $\operatorname{Trp}^{184} \rightarrow$ Arg & - \\
\hline R359Q & 8 & 1193 & 6295 & $\mathrm{CG} A \rightarrow \mathrm{CAA}$ & $\operatorname{Arg}^{359} \rightarrow$ Glu & - Taq I \\
\hline G377S & 9 & 1246 & 6748 & $\underline{\mathrm{GGC}} \rightarrow \underline{\mathrm{AGC}}$ & Gly $^{377} \rightarrow$ Ser & + Pvu II \\
\hline R395P & 9 & 1301 & 6803 & $\overline{\mathrm{C}} \underline{\mathrm{GT}} \rightarrow \overline{\mathrm{C}} \underline{\mathrm{C}} \mathrm{T}$ & $\mathrm{Arg}^{395} \rightarrow$ Pro & + Ban II \\
\hline N396T & 9 & 1304 & 6806 & $\mathrm{~A} \underline{\bar{A} \mathrm{C}} \rightarrow \mathrm{A} \overline{\bar{C}} \mathrm{C}$ & Asn $^{396} \rightarrow \mathrm{Thr}$ & + Rsa I \\
\hline
\end{tabular}

${ }^{\mathrm{a}} \mathrm{See}$ Methods for definition of cDNA and genomic sequence position.

Table 3 Characterization of normal and mutant acid $\beta$-glucosidases expressed in Sf9 cells

\begin{tabular}{|c|c|c|c|c|}
\hline \multirow{2}{*}{$\begin{array}{l}\text { Acid } \beta \text {-glucosidase } \\
\text { allele }\end{array}$} & \multicolumn{2}{|c|}{ Specific activity } & \multirow[t]{2}{*}{ CRIM SA } & \multirow[t]{2}{*}{ 1/CRIM SA } \\
\hline & $\begin{array}{l}\text { Glucosylceramide } \\
\mu \mathrm{mol} / \mathrm{min} / \mathrm{mg}\end{array}$ & $\begin{array}{l}4 \mathrm{mU}-\beta \text {-glucoside } \\
\mu \mathrm{mol} / \mathrm{min} / \mathrm{mg}\end{array}$ & & \\
\hline Normal & $9.6 \times 10^{-2}$ & $3.3 \times 10^{-2}$ & 1.00 & 1.00 \\
\hline Antisense & 0 & $3.3 \times 10^{-4}$ & - & - \\
\hline F109V & $6.7 \times 10^{-3}$ & $1.7 \times 10^{-3}$ & 0.15 & 6.7 \\
\hline W184R & $2.4 \times 10^{-5 b}$ & $3.2 \times 10^{-4}$ & 0.0004 & 2500 \\
\hline R359Q & $1.3 \times 10^{-3}$ & $1.4 \times 10^{-3}$ & 0.016 & 63 \\
\hline G377S & $7.5 \times 10^{-3}$ & $1.5 \times 10^{-3}$ & 0.17 & 5.9 \\
\hline R395P & $5.0 \times 10^{-3}$ & $1.8 \times 10^{-3}$ & 0.045 & 22 \\
\hline N396T & $1.3 \times 10^{-2}$ & $9.8 \times 10^{-4}$ & 0.14 & 7.2 \\
\hline N370S & $2.3 \times 10^{-2}$ & $2.7 \times 10^{-3}$ & 0.18 & 5.5 \\
\hline L444P & $1.3 \times 10^{-3}$ & $8.8 \times 10^{-4}$ & 0.057 & 17.5 \\
\hline
\end{tabular}

${ }^{a}$ CRIM SA = total units of specific activity per cross-reacting immunologic material (CRIM).

${ }^{\mathrm{b}}$ Calculated as CBE inhibitable glucosylceramide-cleaving activity.

\section{Expression and characterization of the missense mutations}

The F109V, W184R, R359Q, G377S, R359P and N396T missense mutation s were expressed in the baculovirus system and characterized (Table3). For comparison, the previously studied N370S and L444P alleles were reexpressed. ${ }^{51,52,54}$ Using the fluorescently-labeled natural substrate, NBD-GC, the expressed normal acid $\beta$-glucosidase allele had approximately $9.6 \times 10^{-2} \mu \mathrm{mol} / \mathrm{min} / \mathrm{mg}(\mathrm{U} / \mathrm{mg})$ of glucosylceramide-cleaving activity in the cell lysates. No activity towards NBD-GC was detected in Sf9 cells infected with the recombinant virus containing the antisense acid $\beta$-glucosidase construct. All the expressed mutants had significantly reduced activities, but were relatively stable (ie there was no change in the specific activity of each mutant over a $2 \mathrm{~h}$ assay period). Of the six new mutants being characterized, the N396T allele had the highest residual activity (14\% of normal). TheF109V, G377S and R395P allel es expressed significant activity with 7, 8 and $5 \%$ of expressed normal activity, respectively. The R359Q crude lysates had slightly less ( $1.4 \%$ of normal), but easily detectable, residual activity. In contrast, the W184R allele had very low, but detectable activity levels $\left(2.4 \times 10^{-5} \mathrm{U} / \mathrm{mg}\right)$, which was inhibitable by $\mathrm{CBE}$, an active site-directed substrate analogue specific for lysosomal acid $\beta$-glucosidase.

Immunoblotting studies were carried out to characterize the expressed normal and mutant acid $\beta$-glucosidase and to determine if the mutations altered stability and/or catalytic efficiency. As shown in Figure1, lane10, the normal human acid $\beta$-glucosidase cDNA produced a multi-band pattern that strongly reacted with polyclonal anti-human acid $\beta$-glucosidase antibodies. Consistent with earlier studies, ${ }^{52}$ treatment with $\mathrm{N}$-Glycanase ${ }^{\mathrm{TM}}$ demonstrated that the multiple bands with molecular weights ranging from $63 \mathrm{kDa}$ to about $56 \mathrm{kDa}$ represented differentially glycosylated forms of the enzyme (data not shown). Similar multi-band patterns were seen for all of the expressed mutant CDNAs. No CRIM was detected in the cells expressing the antisense acid $\beta$-glucosi dase construct (Figure1, lane9).

To assess the level of catalytic efficiency $\left(k_{\text {cat }}\right)$ for the mutant alleles, the specific activities were normalized for the relative amount of enzyme protein, ie cross-reacting immunologic material (CRIM). The CRIM SA was calculated (see Methods section) for each, relative to the expressed normal acid $\beta$-glucosidase (Table3). Of note, the G377S, N396T and F109V mutant proteins (with CRIM SAs of 0.17, 0.14, and 0.15 , respectively) had turnover rates similar to that $(0.18)$ of the mild N370S allele. The R395P mutant protein, with its 22-fold reduced CRIM SA, had a catalytic efficiency (0.045) equivalent to that (0.057) of the L444P mutant enzyme. The R359Q allele was even more severely compromised, having only $1.6 \%$ of normal CRIM SA. Of the expressed alleles, the W184R mutant protein was essentially inactive having a 2500 -fold reduction in turnover rate, and was not characterized further.

To evaluate active site function and to probe the effect of the various amino acid substitutions on the structural integrity of the active site of each expressed mutant enzyme, the affinities of two active site-directed inhibitors, CBE and DNM, were assessed. Due to its severely reduced activity, the 


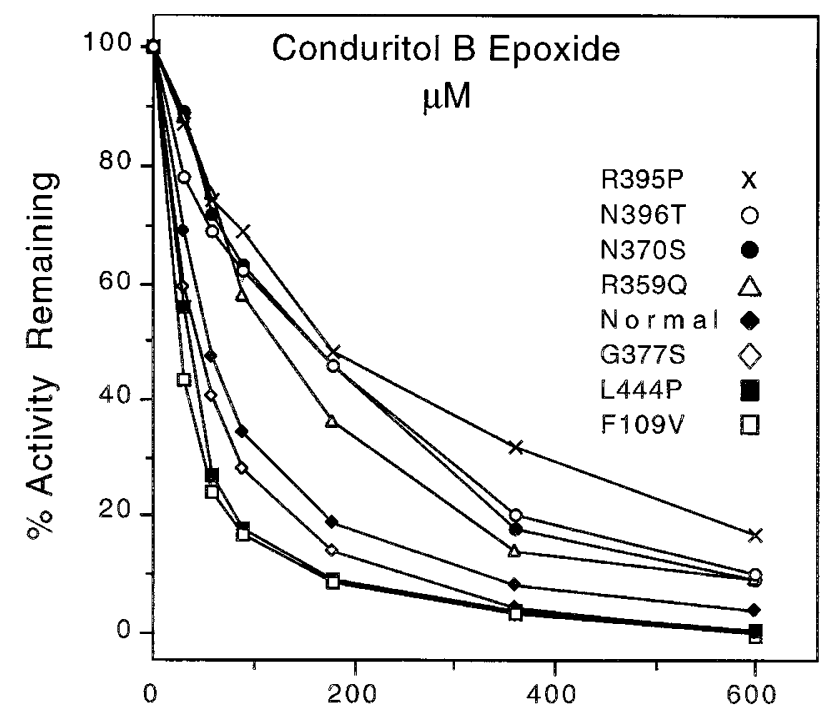

Figure 2 Inhibition of expressed normal and mutant acid $\beta$-glucosidases by the active site inhibitor, CBE $(0-600 \mu \mathrm{M})$. The curve for each mutation is identified by the relative position of its final point from highest to lowest percentage of activity remaining.

W184R mutant was excluded from these studies. For comparative purposes, the previously characterized N370S and L444P alleles were reanalyzed. ${ }^{51,52,60}$ The concentration of CBE required to achieve $50 \%$ inhibition of the initial activity $\left(I_{50}\right)$ was determined. As shown in Figure2, two of the mutant proteins (F109V and G377S) interacted normally with this inhibitor, as did the L444P enzyme, and had $\mathrm{IC}_{50}$ curves that overlapped that of the expressed normal enzyme. The findings classified these mutant proteins as typical 'group A' enzymes. ${ }^{61,62}$ The R359Q, R395P, N396T, and N370S mutant enzymes each had significantly reduced affinity (ie higher $\mathrm{IC}_{50}$ values) towards $\mathrm{CBE}$, categorizing them as 'group $B$ ' enzymes. These results were confirmed by determining the sensitivity of these mutant proteins to a single high concentration of DNM. Assaying the normal enzyme in the presence of $600 \mu \mathrm{M}$ DMN resulted in an approximately $80 \%$ loss of activity towards $4 \mathrm{MU}-\mathrm{Glc}$. The 'group $\mathrm{A}^{\prime}$ enzymes, F109V, G377S, and L444P were similarly affected, with 11, 21 and $11 \%$ activity remaining, respectively. However, the 'group B' enzymes encoded by R359Q, R395P, N396T, and N370S were inhibited less, retaining 54, 72, 63 and 76\% initial activity, respectively.

\section{Discussion}

Molecular analysis of the acid $\beta$-glucosidase gene from 12 unrelated Portuguese type 1 GD patients revealed three novel mutations, and the expression of these, and three other reported, but uncharacterized lesions, ${ }^{12,28,29}$ provided insight into the function of these alleles and potential genotype/ phenotype correlations. The three novel mutations were missense mutations: F109V, the sterically non-conservative substitution ${ }^{63,64}$ of phenylalanine by valine in a weakly conserved (human vs murine ${ }^{65}$ ) region of the acid $\beta$-glucosidase protein; W184R, the non-conservative substitution of a tryptophan residue by the positively-charged arginine in the middle of 15 (amino acids176-189) conserved (in fact, identical ) residues; and R395P, the non-conservative substitution of arginine by proline, involving the loss of a positive charge and introduction of a rigid side chain at residue 395 , which lies in the longest stretch (amino acids315-406) of conserved (ie identical except for amino acid 376) residues in the human and murine sequences, suggesting an important functional domain. The three additional alleles characterized also involved residues within this highly conserved 92 amino acid region of acid $\beta$-glucosi dase which contains the catalytic nucleophile $\left(\mathrm{E}^{340^{66}}\right)$ : R359Q, the non-conservative substitution of an arginine by a glutamine (ie resulting in the loss of a positive charge); G377S, the highly favorable substitution of glycine by serine (both having small polar side chains), especially at residues with surface locations; and N396T, the conservative substitution of asparagine by the physio-chemically similar threonine.

Expression studies provided the opportunity to evaluate the function of the new and previously uncharacterized mutations. The expressed recombinant mutant enzyme proteins either had severely compromised function and/or stability (W184R, R359Q and R395P), or had significant residual catalytic activity (F109V, G377S and N396T). Little, if any, functional enzyme was produced from the W184R, R359Q or R395P alleles, consistent with these mutants having severe charge or size changes in highly conserved regions of the coding sequence. Presumably, these lesions must be heteroallelic with a neuroprotective allele, such as N370S, for a type 1 disease phenotype.

Of note, the three mutations with significant residual activity had CRIM SA values (ranging from 0.14 to 0.17 ) similar to that $(0.18)$ of the well-characterized common N370S allele, the 'neuroprotective' allele in type 1 GD even when heteroallelic with the most severely compromised acid $\beta$-glucosidase mutation. The finding that patients homoallelic for either G377S or N396T were essentially asymptomatic or had mild disease (Table 1) suggests that these lesions also are neuroprotective. The identification of type 1 GD patients heteroallelic for either G377S or N396T and a putative or known severe allele would further substantiate the neuroprotective effect of these mutations.

In Portugal, type 1 GD is the most prevalent Iysosomal storage disorder. The frequency of the N370S, L444P, G377S and N396T mutations in the Portuguese GD patients was reported as $53.7 \%, 13 \%, 7.4 \%$ and $5.6 \%$, respectively. ${ }^{12}$ Screening for these frequent mutations usually allows the detection of at least one allele in Portuguese patients. To date, the N396T Iesion has only been reported in Portuguese type 1 GD patients. ${ }^{12}$ In contrast, the G377S allele also has been reported in Spanish type1 patients ${ }^{67}$ and in a Portuguese Sephardic Jewish patient who was homoallelic for G377S, 
suggesting that the G377S mutation may have Sephardic ancestry. Of note, the finding of three presumably un related patients homoallelic for the G377S allele and four presumably unrelated patients hetero- or homoallelic for the N396T lesion suggests that these lesions have common ancestral founders in the Portuguese population.

\section{Acknowledgements}

The authors thank the physicians, patients and their relatives who participated in these studies. The technical assistance of Ms E Pinto is gratefully acknowledged. This work was supported in part by a grant (6-FY96-1062) from the March of Dimes Birth Defects Foundation (MEG) and by grants BD/5547/95 (OA), BIC1542 (AM) and PECS/T/SAU/88/95 from JNICT/FCT (Portugal) (MCSM).

\section{References}

1 Beutler E, Grabowski GA: Gaucher disease. In: Scriver CR, Beaudet AL, Sly WS, Valle D (eds). The M etabolic Basis of Inherited Disease, McGraw Hill: New York, 1994, pp 2641-2670.

2 Desnick RJ, Gatt S, Grabowski GA: Gaucher Disease: A Century of Delineation and Research. Alan Liss: New York, 1982.

3 Cox TM, Schofield JP: Gaucher's disease: Clinical features and natural history. Ballière's Clin Haematol 1997; 10: 657-689.

4 Sorge J, West C, Westwood B, Beutler E: Molecular cloning and nucleotide sequence of human glucocerebrosidase CDNA. Proc Natl Acad Sci 1985; 82: 7289-7293.

5 Tsuji S, Choudary PV, Martin BM, Winfeild S, Barranger JA, Ginns El: Nucl eotide sequence of CDNA containing the complete coding sequence for human cerebrosidase. J Biol Chem 1986; 261: 50-53.

6 Horowitz M, Wilder S, Horowitz Z, Reiner O, Gelbart T, Beutler E: The human glucocerebrosidase gene and pseudogene: Structure and evolution. Genomics 1989; 4: 87-96.

7 Grabowski GA, Horowitz M: Gaucher's disease: Molecular, genetic and enzymological aspects. Baillière's Clin Haematol 1997; 10: 635-656.

8 Beutler E, Gelbart T: Hematologically important mutations: Gaucher disease. Blood Cells Molec Dis 1998; 24: 2-8.

9 Krawczak M, Cooper DN: The human gene mutation database. Trends Genet 1997; 13: 121-122.

10 Horowitz M, Pasmanik-Chor M, Borochowitz Z et al: Prevalence of glucocerebrosidase mutations in the Israeli Ashenazi Jewish population. Hum Mutat 1998; 12: 240-244.

11 Beutler E, Nguyen N, Henneberg M et al: Gaucher disease: gene frequencies in the Ashkenazi Jewish population. Am J Hum Genet 1993; 52: 85-88.

12 Amaral O, Pinto E, Fortuna M, Lacerda L, Sá Miranda MC: Type1 Gaucher disease: identification of N396T and prevalence of glucocerebrosidase mutations in the Portuguese. Hum Mutat 1996; 8: $280-281$.

13 Lacerda L, Amaral O, Pinto R, Oliveira P, Aerts J, Sá Miranda MC: Gaucher disease: N370S glucocerebrosidase gene frequencies in the general population. Clin Genet 1994; 45: 298-300.

14 Beutler E: Gaucher disease: New molecular approaches to diagnosis and treatment. Science 1992; 256: 794-799.

15 Beutler E: Gaucher disease as a paradigm of current issues regarding single gene mutations of humans. Proc N atl Acad Sci USA 1993; 90: 5384-5390.

16 Horowitz M, Zimran A: Mutations causing Gaucher disease. Hum Mutat 1994; 3: 1-11.

17 Erikson A, Bembi B, Schiffman R: Neuronopathic forms of Gaucher disease. Clinic Haematology 1997; 10: 711-723.

18 Levy-Lahad E, Zimran A: Gaucher's disease: Genetic counselling and population screening. Baillière's Clin Haematol 1997; 10: 779-792.
19 Sibille A, Eng C, Kim S-J, Pastores G, Grabowski GA: Phenotype/ genotype correlations in Gaucher disease type1: Clinical and therapeutic implications. Am J Hum Genet 1993; 52: 1094-1101.

20 Zimran A, Sorge J, Gross E, Kubitz M, West C, Beutler E: Prediction of severity of Gaucher's disease by identification of mutations at DNA level. Lancet 1989; 2: 349-352.

21 Tsuji S, Choudary P, Martin B et al: A mutation in the human glucocerebrosidase gene in neuronopathic Gaucher's disease. N Engl J Med 1987; 316: 570-575.

22 Eto $\mathrm{Y}$, Kawame $\mathrm{H}$, Hasegawa $\mathrm{Y}$, Ohashi $\mathrm{T}$, Ida $\mathrm{H}$, Tokoro $\mathrm{T}$ : Molecular characteristics in Japanese patients with lipidosis: Novel mutations in metachromatic leukodystrophy and Gaucher disease. Mol Cell Biochem 1993; 119: 179-184.

23 Masuno M, Tomatsu S, Sukegawa K, Orii T: Non-existence of a tight association between a ${ }^{444}$ leucine to proline mutation and phenotypes of Gaucher disease: High frequency of a Ncil polymorphism is the non-neuronopathic form. Hum Genet 1990; 84: 203-206.

24 Sá Miranda MC: Phenotypic and genotypic characterization of different Gaucher populations: European/Asian patients with Gaucher Disease. NIH Technology Assessment Conference. Gaucher Disease 1995: 61-65.

25 Zimran A, Kay A, Gelbart T et al: Gaucher disease. Clinical, laboratory, radiologic, and genetic features of 53 patients. Medicine 1992; 71: 337-353.

26 Tayebi N, Reissner K, Lau E et al: Genotypic heterogeneity and phenotypic variation among patients with type 2 Gaucher disease. Ped Res 1998; 43: 571-578.

27 Amaral O, Marcao M, Pinto E, Sá Miranda M: Mutation analyses of the three most common lysosomal storage disorders in Portugal. Eur J Hum Genet 1998; 6 (Sl): P1.027.

28 Kawame H, Haseqawa Y, Eto Y, Maekawa K: Rapid identification of mutations in the glucocerebrosidase gene of Gaucher disease patients by analysis of singlestrand conformation polymorphisms. Hum Genet 1992; 90: 294-296.

29 Laubscher KH, Glew RH, Lee RE, Okinaka RT: Use of denaturing gradient gel electrophoresis to identify mutant sequences in the $\beta$-glucocerebrosidase gene. Hum Mut 1994; 3: 411-415.

30 Miller S, Dykes D, Polesky H: A simple salting out procedure for extracting DNA from human nucleated cells. Nucleic Acids Res 1998; 16: 1215.

31 Beutler E, Gelbart T, Kuhl W, Zimran A, West C: Mutations in Jewish patients with Gaucher disease. Blood 1992; 79: 1662-1666.

32 Beutler E, Gelbart T, West C: Short communication: identification of six new Gaucher disease mutations. Genomics 1993; 15: 203-205.

33 He G-S, Grabowski GA: Gaucher disease: A G ${ }^{+1} A^{+1}$ IVS2 splice donor site mutation causing exon 2 skipping in the acid $\beta$-glucosidase mRNA. Am J Hum Genet 1992; 51: 810-820.

34 Graves PG, Grabowski GA, Eisner RI, Palese P, Smith FI: Gaucher disease: cloning and characterization of a CDNA encoding acid $\beta$-glucosidase from an Ashkenazi Jewish patient. DNA 1988; 7: 521-528.

35 Eyal N, Firon N, Wilder S, Kolodny EH, Horowitz M: Three unique base pair changes in a family with Gaucher disease. Hum Genet 1991; 87: 328-332.

36 Latham TE, Theophilus BD, Grabowski GA, Smith FI: Heterogeneity of mutations in the acid $\beta$-glucosidase gene of Gaucher disease patients. DNA Cell Biol 1991; 10: 15-21.

37 Beutler E, Gelbart T: Gaucher disease associated with a unique $\mathrm{Kpnl}$ restriction site: identification of the amino acid substitution. Ann Hum Genet 1990; 54: 149-153.

38 Eyal N, Wilder S, Horowitz P: Prevalent and rare mutations among Gaucher patients. Gene 1990; 96: 277-283.

39 Tsuji S, Martin BM, Barranger JA, Stubblefield BK, LaMarca ME, Ginns El: Genetic heterogeneity in type1 Gaucher's disease: multiple genotypes in Ashkenazic and non-Ashkenazic individuals. Proc Natl Acad Sci USA 1988; 85: 2349-2352. 
40 Theophilus BD, Latham T, Grabowski GA, Smith FI: Comparison of RNase A, a chemical cleavage and GC-clamped denaturing gradient gel electrophoresis for the detection of mutations in exon 9 of the human acid $\beta$-glucosidase gene. Nucleic Acids Res 1989; 17: 7707-7722.

41 Wigderson M, Firon N, Horowitz Z et al: Characterization of mutations in Gaucher disease patients by CDNA cloning. Am J Hum Genet 1989; 44: 365-377.

42 Hong CM, Ohashi T, Yu X, Weiler S, Barranger JA: Sequence of two alleles responsible for Gaucher disease. DNA Cell Biol 1990; 9: 233-241.

43 Beutler E, Gelbart T, Kuhl W, Sorge J, West C: Identification of the second common Jewish Gaucher disease mutation makes possible population based screening for the heterozygote state. Proc Natl Acad Sci 1991; 88: 10544-10547.

44 Beutler E, Gelbart T, West C: The facile detection of the nt 1226 mutation of glucocerebrosidase by 'mismatched' PCR. Clin Chim Acta 1990; 194: 161-166.

45 Amaral O, Fortuna AM, Lacerda L, Pinto R, Sá Miranda MC: Molecular characterization of type 1 Gaucher disease families and patients: Intrafamilial heterogeneity at the clinical level. J Med Genet 1994; 31: 401-404.

46 Amaral O, Lacerda L, Santos R, Pinto RA, Aerts H, Sá Miranda MC: Type1 Gaucher disease: Molecular, biochemical, and clinical characterization of patients from Northern Portugal. Biochem Med Metab Biol 1993; 49: 97-107.

47 Sorge J, West C, Westwood B, Beutler E: Correction. Proc Natl Acad Sci USA, 1985, 19 82: 7289-7293. Proc Natl Acad Sci USA 1986; 83: 3567.

48 Beutler E, West C, Gelbart T: Polymorphisms in the human glucocerebrosidase gene. Genomics 1992; 12: 795-800.

49 Taylor JW, Ott J, Eckstein F: The rapid generation of oligonucleotide-directed mutations at high frequency using phosphorothioate-modified DNA. Nucleic Acids Res 1985; 13: 8765-8785.

50 Taylor JW, Schmidt W, Cosstick R, Okruszek A, Eckstein F: The use of phosphorothioate-modified DNA in restriction enzyme reactions to prepare nicked DNA. Nucleic Acids Res 1985; 13: 8749-8764.

51 Grace ME, Newman KM, Scheinker V, Berg-Fussman A, Grabowski GA: Analysis of human acid $\beta$-glucosidase by site-directed mutagenesis and heterologous expression. J Biol Chem 1994; 269: 2283-2291.

52 Grace ME, Desnick RJ, Patores GM: Identification and expression of acid $\beta$-glucosidase mutations causing severe type 1 and neurologic type 2 Gaucher disease in non-Jewish patients. J Clin Invest 1997; 99: 2530-2537.

53 O'Reilly D, Miller L, Luckow V: Baculovirus Expression Vectors: A Laboratory Manual, Oxford University Press: New York, 1994.

54 Grace M, Graves P, Smith F, Grabowski G: Analyses of catalytic activity and inhibitor binding of human acid $\beta$-glucosidase by site-directed mutagenesis. J Biol Chem 1990; 265: 6827-6835.
55 Grace M, Berg A, He G, Goldberg L, Horowitz M, Grabowski G: Gaucher disease: Heterologous expression of two alleles associated with neuronopathic phenotypes. Am J Hum Genet 1991; 46: 646-655.

56 Aerts J, Donker-Koopman W, Brul S et al: Comparative study on glucocerebrosidase in spleens from patients with Gaucher disease. Biochem J 1990; 269: 93-100.

57 Schagger H, von Jagow G: Tricine-sodium dodecyl sulfate-polyacrylamide gel electrophoresis for the separation of proteins in the range from 1 to $100 \mathrm{kDa}$. Anal Biochem 1987; 166: 368-379.

58 Dinur T, Grabowski GA, Desnick RJ, Gatt S: Synthesis of a fluorescent derivative of glucosyl ceramide for the sensitive determination of glucocerebrosidase activity. Anal Biochem 1984; 136: 223-234.

59 Sá Miranda MC, Aerts J, Pinto R et al: Activity of glucocerebrosidase in extracts of different cell types from type 1 Gaucher disease patients. Clin Genet 1990; 38: 218-227.

60 Grace M, Smith F, Latham T, Horowitz M, Berg A, Grabowski GA: Gaucher disease: Heterologous expression of two alleles associated with neuronopathic phenotypes. Am J Hum Genet 1990; 47: A156.

61 Grabowski GA, Goldblatt J, Dinur T et al: Genetic heterogeneity in Gaucher disease: physicokinetic and immunological studies of the residual enzyme in cultured fibroblasts from non-neuronopathic and neuronopathic patients. Am J Med Genet 1985; 21: 529-549.

62 Grabowski GA, Dinur T, Osiecki KM, Kruse JR, Legler G, Gatt S: Gaucher disease types 1,2, and 3: Differential mutations of the acid $\beta$-glucosidase active site identified with conduritol B epoxide derivatives and sphingosine. Am J Hum Genet 1985; 37: 499-510.

63 Bordos D, Argos P: Suggestions for 'safe' residue substitutions in site-directed mutagenesis. J Mol Biol 1991; 217: 721-729.

64 Hutchinson C, Swanstrom R, Loebe D: Complete mutagenesis of protein coding domains. Meth Enzymol 1991; 202: 356-390.

65 O'Neill RR, Tokoro T, Kozak CA, Brady RO: Comparison of the chromosomal localization of murine and human glucocerebrosidase genes and of the induced amino acid sequences. Proc Natl Acad Sci USA 1989; 86: 5049-5053.

66 Miao S, McCarter JD, Grace ME, Grabowski GA, Aebersold R, Withers SG: Identification of $\mathrm{Glu}^{340}$ as the active-site nucleophile in human glucocerebrosidase by use of electrospray tandem mass spectrometry. J Biol Chem 1994; 269: 10975-10978.

67 Pocovi M, Cenarro A, Civeira F et al: Beta-glucocerebrosidase gene locus as a link for Gaucher's disease and familial hypo-alphalipoproteinaemia. Lancet 1998; 351: 1919-1923. 